\title{
Evaluation of Fire Disaster Emergency Response Capacity using Open-source Data and Response Time Analysis in Ilorin Metropolis
}

\author{
Ahmadu H. A., * Idrees M. O., Omar D. M., Yusuf A., Ipadeola O. A., Alade \\ A. K. and Abdulyekeen A. O. \\ Department of Surveying and Geoinformatics, Faculty of Environmental Science, University of Ilorin, P.M.B. \\ 1515, Ilorin, Nigeria \\ Corresponding Author: *ahmadu.ha@unilorin.edu.ng
}

https://doi.org/10.36263/nijest.2021.02.0281

\begin{abstract}
This study evaluates the response capacity to fire disaster emergency response system in Ilorin metropolis using Open-source data and response time analysis. Road and street information were obtained from Geofabrik. In addition, coordinates of fire service stations and fire disaster risk spots, specifically fuel and gas stations were acquired using Garmin 76X handheld GPS. Using the relationship of the length of road segments and speed, the travel time was computed in ArcGIS 10.4 environment. With the Network analyst tool, the response capability of the fire stations was evaluated at different response times $(1,2$, and 3 minutes) based on service area coverage. The results showed that the fire stations could only cover $0.24 \%, 0.68 \%$, and $1.22 \%$ of the service area within 1-, 2- and 3-minute response time, respectively, whereas $97.86 \%$ of the metropolis requires longer time (>3 minutes). Finding from this study has revealed the inadequacy of the existing fire disaster emergency response system to effectively cover the city. This will be useful for local and state governments in policy directives on strengthening fire disaster emergency response structure.
\end{abstract}

Keywords: Fire disaster, Response capability, Flashover, Response time, Ilorin, Geofabrik

\subsection{Introduction}

Fire disaster, including wild forest and urbanized areas, has become a common incident globally (Menya and K'Akumu, 2016). In recent times, Nigeria has witnessed several incidents of fire outbreaks across several states. Notable incidences include the fire outbreak that engulfed the treasury house in Abuja on $8^{\text {th }}$ April 2020, the incidence at Katsina state central market on $22^{\text {nd }}$ March 2021, that left goods and properties worth millions of naira destroyed, and the incidence at a market in Ibadan on $3^{\text {rd }}$ April 2021, where goods and properties worth millions of naira were destroyed (Nwachukwu, 2020; Micheal, 2021; Kabir, 2021). Notable incidences in Ilorin, Kwara state include; the fire outbreak at the Nigerian Television Authority, Ilorin on $22^{\text {nd }}$ July 2020, the incidence at Ipata market, Ilorin on $21^{\text {st }}$ December 2020, where goods and properties worth millions of Naira were destroyed and the incidence at an apartment in Tanke, Ilorin on $19^{\text {th }}$ March 2021, where five people were burnt to death (Adebayo, 2021; Jimoh, 2020; Akinyemi, 2021).

Just like other disasters, fire outbreaks usually have devastating effects, including loss of lives and properties worth millions of dollars, environmental degradation, economic and social losses (Adab et al., 2013; Malik et al., 2013; Kim et al., 2016). Although when and where a fire disaster will happen cannot be predicted, losses could be reduced through an effective emergency disaster response system (Marrion, 2016). Fire disaster emergency response system requires the proper location of fire service stations with respect to societal and environmental components such as population growth, urbanization, and industrialization upon which fire incidents are categorized as either domestic or industrial fires (Waheed, 2014; Addai et al., 2016; Granda and Ferreira, 2018). Owing to this, there are the need for fire disaster emergency response systems to be frequently evaluated to ascertain their capability to promptly respond to fire incidences that might occur in an area. 
Several studies have evaluated fire disaster emergency response capability. For instance, Xia-tao and Li-ping (2009) report a comprehensive evaluation model developed based on fuzzy analytic hierarchical process and used to evaluate fire disaster response capability of Zhengzhou city, Henan province. Their results showed that the level of the emergency response capability of the community was standard, and it satisfied the emergency needed. Similarly, Chen et al. (2019) evaluated emergency rescue capability on urban fire stations in Zhengzhou city, China using the fuzzy comprehensive elevation (FCE) method to analyze the decision problem, and analytical hierarchical process (AHP) to determine the weight of each index included in the system. The research work of Guofengma et al. (2019) evaluated building fire emergency response capacity based on the Capacity Maturity Model (CMM), with a plugin for evaluating fire emergency response capability which they developed based on the building information modelling (BIM) platform. While the research work of Zhang et al. (2019) evaluated the emergency rescue capability of general aviation enterprises under specific rescue demand using a constructed model based on Quality Function Development (QFD). Their model was used to evaluate the rescue capability of a general aviation enterprise after an Earthquake.

Ilorin metropolis has witnessed a rapid increase in population and urbanization over the last three decades. Records from the National Population Commission put the population of Ilorin as 532,088 in 1991 and projected to 3,518,771 by 2020 (Ibrahim et al., 2014). This indicates that the risk of fire disaster occurrence in Ilorin could increase. This study investigates fire disaster emergency response capability based on travel time metrics in Ilorin metropolis using GIS.

\subsection{Methodology}

\subsection{Materials}

Ilorin, the Kwara state capital, is located within Latitude $8^{\circ} 29^{\prime} 43^{\prime \prime} \mathrm{N} \& 8^{\circ} 30^{\prime} 50^{\prime \prime} \mathrm{N}$ and Longitude $4^{\circ}$ $31^{\prime} 48^{\prime \prime} \mathrm{E} \& 4^{\circ} 35^{\prime} 40^{\prime \prime} \mathrm{E}$ (Figure 1). Ilorin metropolis is comprised of three local government areas, namely, Ilorin West, Ilorin East, and Ilorin south. Ilorin is highly populated with people from different tribes including Yoruba, Igbo, Hausa, and Fulani. The two main religions practiced in Ilorin are Islam and Christianity.

The city is relatively developed, hosting several industrial establishments including Olam International (Africa's biggest Cashew processing plant), Dangote flour mills, Tuyil Pharmaceutical, KAMWIL, Chellaran motorcycle assembly plant (Saad, 2013). Ilorin is also home to several tertiary institutions like the University of Ilorin, Kwara State University, Al-Hikmah University, Kwara Polytechnics, College of Education, and many others. The major roads in Ilorin are very good, and they provide access to several small and medium scale businesses including; Banks, Hotels, Restaurants, markets, and supermarkets. The service area considered in this study covers Ilorin south, Ilorin east, and west local government area.
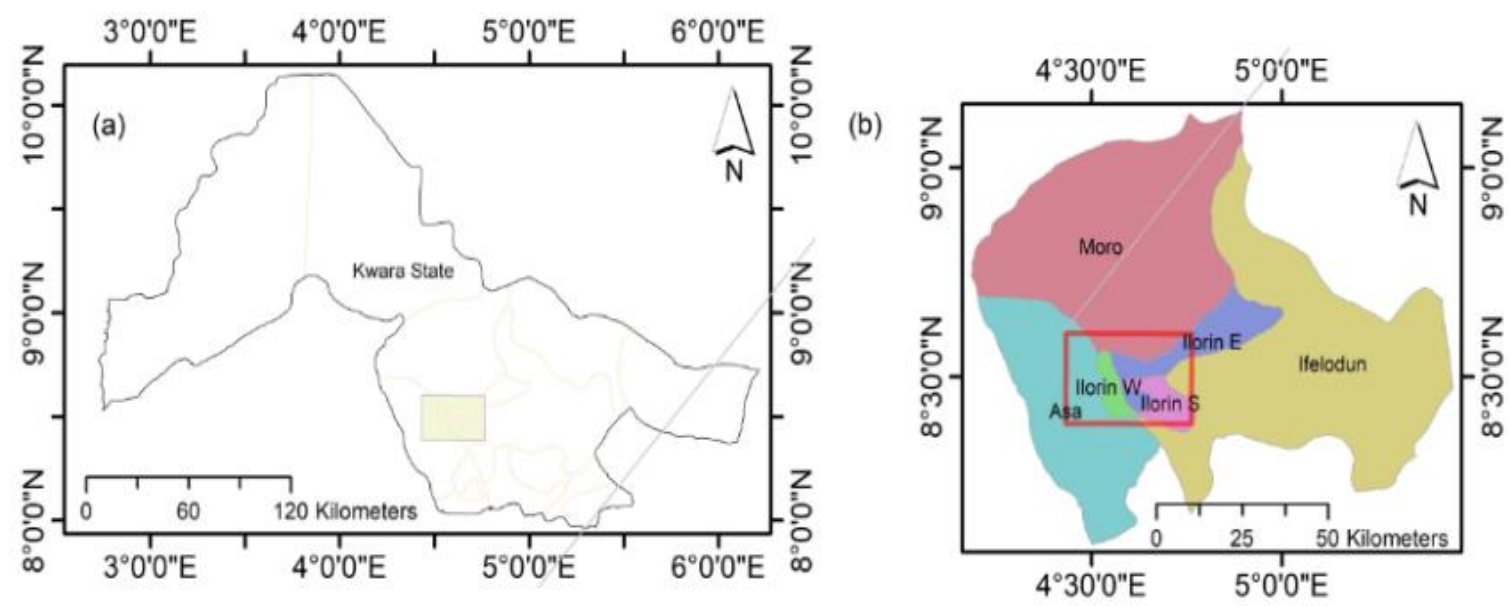

Figure 1: Location of the Study Area 
The datasets used in this study were obtained from online sources and the field. We obtained road and street information from Geofabrik (https://www.geofabrik.de/). Geofabrik, in German - "GeoFactory" is a Volunteered Geographic Information (VGI) downloadable in OSM-XML and Shapefile (SHP) formats (Khim Bahadur et al., 2019). One of the advantages of Geofabrik is that the data is updated daily (Zielstra and Zipf, 2010), providing reliable and up-to-date geodata for different applications. Also, the location coordinates of fire ignition hotspots, particularly fuel stations and hospitals, were collected using Garmin GPSMAP 78 handheld GPS. The 195 fuel stations and 33 hospitals collected during the fieldwork and the road information clipped using the boundary file were combined in the GIS environment for the analysis. Figure 2 presents the data acquisition, processing, and analysis workflow.

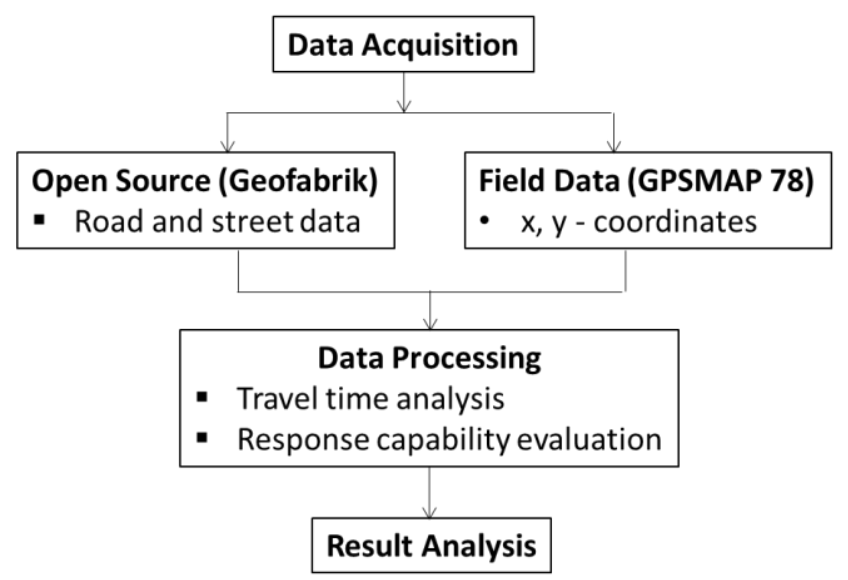

Figure 2: Data acquisition and processing

\subsection{Methods}

Response capability of the two fire stations was evaluated utilizing the service area coverage based on travel time analysis. That is a region that covers streets that are within a specified impedance. The service area analysis was used to reveal the extent of service coverage using drive time (Equation 1) polygons that show the region each fire station can cover effectively at different response times. In this study, the drive time from a fire station to a fire disaster incident was considered to be the response time.

$T=L / S$

where $T$ is the travel time, $L$ is the length of the route and $S$ is the speed.

The length of each route and the drive time were determined using the geometry calculator (Equation 1) in ArcMap. Based on the National Fire Protection Association (NPFA) recommendation of a maximum speed limit of $68 \mathrm{mph}$ for fire apparatus of more than 26000 pounds (Peters, 2008), a drive speed of $68 \mathrm{mph}$ was adopted for the drive speed of fire service trucks. Driving restrictions were not considered in this research since the world emergency response codes (CODE3) (IAFC, 2006) allows for emergency service responder to use lights and sirens to clear traffic way in the event of lifethreatening incident.

In this study, the emergency response capability of the three fire service stations in Ilorin to fire incident has been evaluated based on the travel time of 1 to 3 minutes. Fire outbreaks usually require immediate response of fire disaster emergency services. Usually, the most important consideration is to arrive at the scene of the fire incident before it progresses to a flashover (Klaene, 2015; Shikoli, 2015). Flashover occurs when surfaces and objects in the scene of the outbreak get heated to ignition temperature (ranging from $1000^{\circ} \mathrm{F}$ to $1500^{\circ} \mathrm{F}$ ) resulting in an instantaneous outburst of flame (IFSTA, 2008). The work of Dehaan (2002) has shown that for a standard furnished room with no accelerants, flashover occurs 210 seconds ( 3.5 minutes) after ignition. This implies that an emergency responder must appropriately act within 3.5 minutes before a fire event reaches flashover. 


\subsection{Results and Discussion}

The result of data processing is presented in Figure 3, which shows the road network, fire stations, and fire disaster risk spots which are mainly fuel and gas stations. The location of the two fire stations with respect to their expected service areas can be observed from the map. Response capability largely depends on the accessibility of the firefighting trucks from a station to fire emergency call.

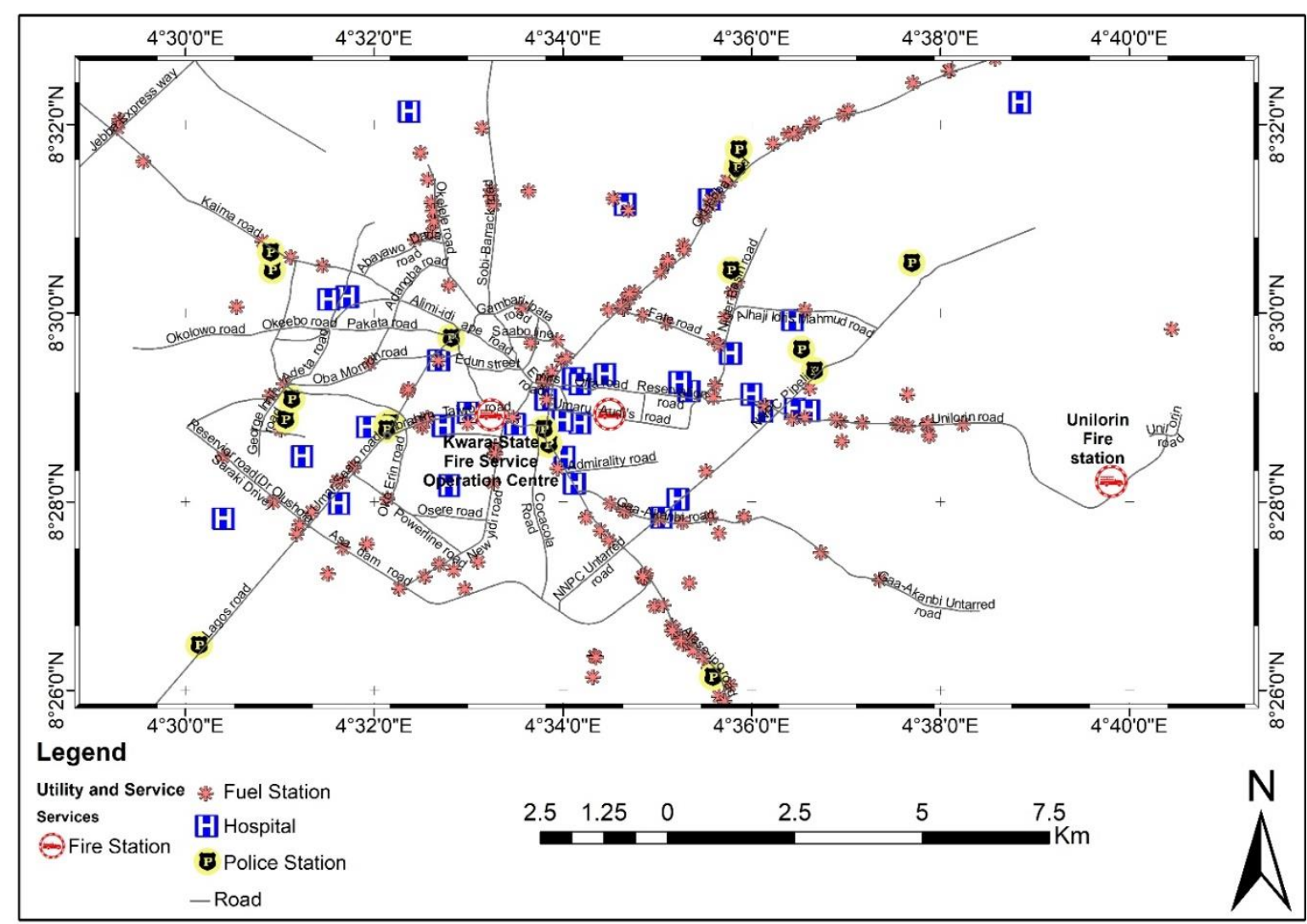

Figure 3: Road network and location of the fire service stations and potential fire ignition points

The result of response capability to fire incident based on travel time is presented in Figure 4 and Table 1 . The drive time polygons show service area covered by the three fire stations within 1-, 2- and 3-minutes response time. The analysis has shown that the three fire stations can, within 1-, 1 to 2- and 2 to 3 -minute travel time, cover $0.24 \%, 0.68 \%$, and $1.22 \%$ of the service area, respectively. This implies that fire incidents within $2.14 \%$ of the area under consideration can be effectively responded to before the flame reaches flashover. The remaining parts which constitutes $97.86 \%$ of the area (critical zone) exceeds the response time required to put out fire outbreak. 


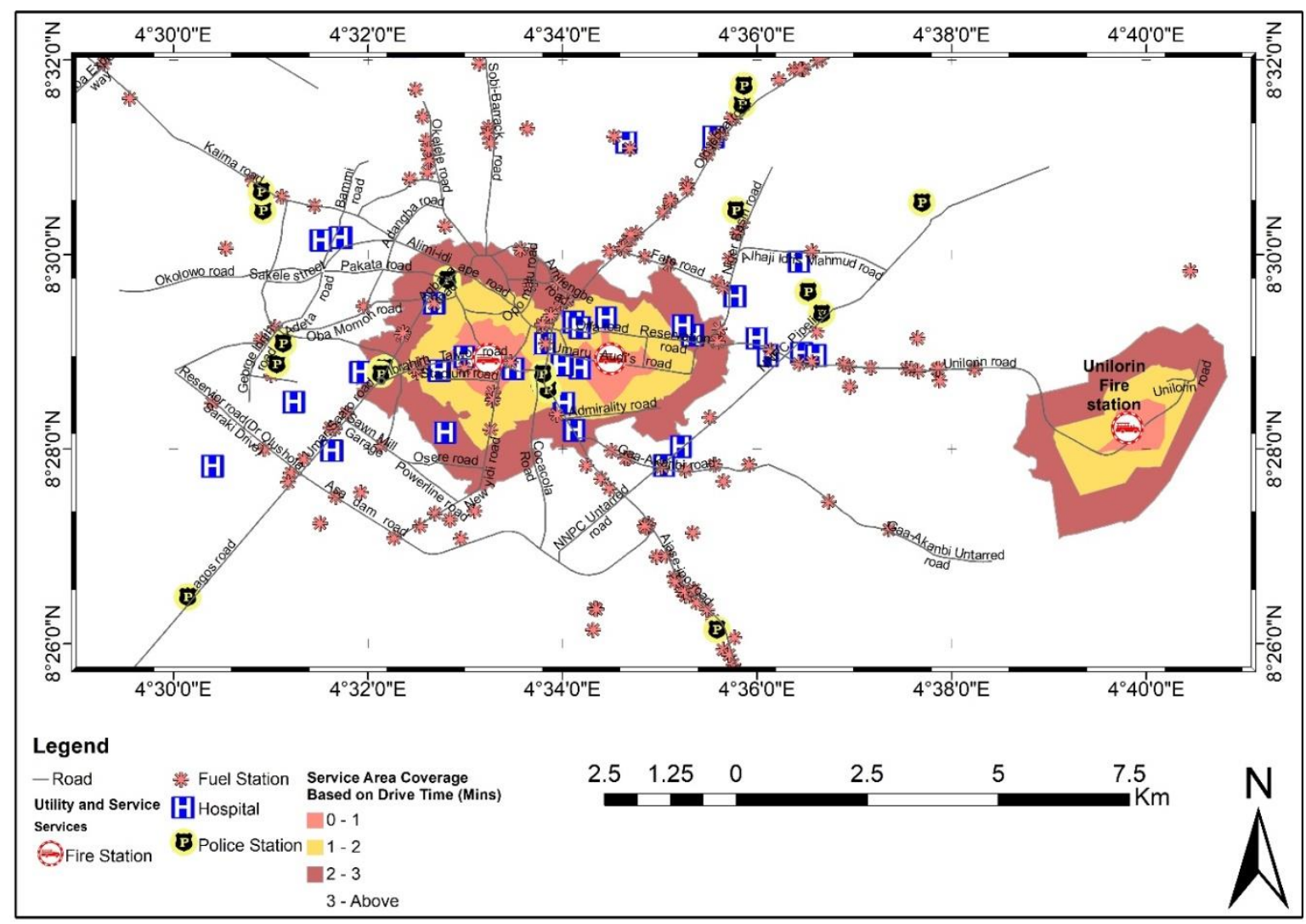

Figure 4: Service area response capability at different response times

Table 1: Travel time and service area coverage

\begin{tabular}{llll}
\hline Drive time polygon & $\begin{array}{l}\text { Response time (in } \\
\text { minutes) }\end{array}$ & $\begin{array}{l}\text { Percentage Area } \\
\text { covered }\end{array}$ & $\begin{array}{l}\text { Number of risk } \\
\text { spots }\end{array}$ \\
\hline 1 & $0-1$ & 0.24 & 6 \\
2 & $1-2$ & 0.68 & 19 \\
3 & $2-3$ & 1.22 & 21 \\
Critical zone & $3+$ & 97.86 & 152 \\
\hline
\end{tabular}

Evidently, there are more fire risk spots within areas identified as critical zone that constitutes the larger percentage of the metropolis, an indication that the most parts of the city cannot be responded to in 3 minutes response time.

Findings reveal that evaluation of fire disaster emergency response capability using open-source data and response time analysis is very effective. In comparison with the research work of Chen et al. (2019), in which the rescue capability of urban fire stations in Zhengzhou city was evaluated based on Fuzzy Comprehensive Evaluation (FCE) and AHP (which revealed the response system as satisfactory), Ilorin metropolis has few fire stations and poor road network accessibility. However, we believe the performance of Ilorin fire disaster emergency response system can be improved if more fire stations are established, and road network accessibility is improved upon.

\subsection{Conclusion}

In this study, we employed Open-source data and response time analysis to evaluate fire disaster emergency response capability in Ilorin metropolis. Our findings showed that in case of any fire outbreak, $2.14 \%$ of the service area could be responded to within 3 minutes, which is sufficient to put a fire outbreak under control before it progresses into a flashover. The study also revealed that $97.86 \%$ of the service area needed a response time above 3 minutes before fire outbreaks can be put under control. We believe that this level of response capability is not sufficient, because, in a situation where fire disaster breaks out in most parts of the city where accessibility is poor due to bad road and long-distance from fire stations, the emergency response system cannot put it under control before it progresses into a flashover. Hence, the fire disaster emergency response system needs to be strengthened, and further studies are necessary to determine the number of additional fire stations 
needed, and where they should be placed to achieve effective and complete coverage within the recommended 3 minutes response time.

\section{References}

Adab H., Kanniah K. D. and Solaimani, K. (2013). Modeling forest fre risk in the northeast of Iran using remote sensing and GIS techniques. Nat. Hazards, 65, pp. 1723-1743.

Addai, E. K., Tulashie, S. K., Annan, J. and Yeboah, J. (2016). Trend of fire outbreaks in Ghana and ways to prevent these incidents. Safety and Health work, 7, pp. $284-292$.

Adebayo, A. (2020). Late-night fire razes NTA Ilorin. [online] Daily Post. Available at: www.dailypost.ng/2020/07/22/late-night-fire-razes-nta-ilorin [Accessed $3^{\text {rd }}$ March 2021].

Akinyemi, D. (2021). Four siblings, mother burnt to death in Ilorin inferno. [online] Vanguard. Available at: www.vanguardngr.com/2021/03/4-siblings-mother-burnt-to-death-in-ilorin-inferno [Accessed 3rd March 2021].

Chen, M., Wang, K. and Li, H. (2019). Emergency rescue capability evaluation on urban fire stations in china. Process safety and Environmental protection, pp. 1 - 19.

Dehaan, J. (2002). Kirk's fire investigation, $5^{\text {th }}$ Ed. Prentice-Hall, USA.

Granda, S. and Ferreira, T. M. (2018). Assessing vulnerability and fire risk in old urban areas: Application of the historical center of Guimaraes. Fire Technology, pp. $1-23$.

Guofeng Ma, Tan, S., and Shang, S. (2019). The evaluation of Building fire emergency response capability based on the CMM. International Journal of Environmental Research and public health, pp. $1-15$.

Ibrahim, R. B., Bako, A. I., Raheem, W. M. and Abdulyekeen, A. O. (2014). Appraisal of urbanization trends in Ilorin, Nigeria. Journal of sustainable development in Africa, 16(8), pp. 1 - 15 .

International Association of Fire Chiefs (2006). Guide to IAFC model policies and procedures for emergency vehicle safety. www.iafc.org.

International Fire Service Training Association (2008). Essentials of Fire Fighting (5 $5^{\text {th }}$ ed.). FPP/IFSTA.

Jimoh, A. (2020). Fire guts eleven shops in Kwara market. [online] The Nation. Available at: www.thenationonline.ng.net/fire-guts-11shops-in-kwara-market. [Accessed $5^{\text {th }}$ March 2021].

Kabir, A. (2021). Fire razes Ibadan auto spare parts market. [online] Premium Times. Available at: www.premiumtimes.ng.com/regional/ssouth-west/453014-fire-razes-ibadan-auto-spare- parts-market [Accessed $5^{\text {th }}$ March 2021].

Khim Bahadur, K. C., Koju, N. P., Bhusal, K. P., Low, M., Ghimire, S. K., et al., (2019). Factors influencing the presence of the endangered Egyptian Vulture Neophron Percnopterus in Rukum, Nepal. Global Ecology and Conservation. Global Ecology and Conservation, vol. 20, pp. 1 - 6.

Kim, S., Lee, W., Park, Y., Lee, H. and Lee, Y. (2016). Forest fire monitoring system based on Aerial image. $3^{\text {rd }}$ International conference on information and communication technologies for disaster management.

Klaene, B. J. (2015). Structural firefighting: Strategy and tactics. Jones \& Bartlett Learning, USA.

Malik, T., Rabbani, G. and Farooq, M., (2013). Forest fire zonation using remote sensing and GIS technology in Kansrao forest range of Rajaji national park, Uttarkhand, India. International journal of advanced remote sensing and GIS, 2, pp. 86-95. 
Marrion, C. E. (2016). More effectively addressing fire/disaster challenges to protect our cultural heritage. Journal of Cultural Heritage, 20, pp. $746-749$.

Menya, A. A. and K'Akumu, O. A. (2016). Inter-agency collaboration for fire disaster management in Nairobi city. Journal of urban management, 5, pp. $32-38$.

Micheal, D. (2021). Fire razes Katsina central market. [online] The Guardian. Available at: www.guardian.ng/news/fire-razes-katsina-central-market [Accessed $5^{\text {th }}$ March 2021].

Peters, C. W. (2008). Changes to NPFA 1901, standard for Automotive fire apparatus. [online] NPFA. Available at: www.fireengineering.com [Accessed $10^{\text {th }}$ March 2021].

Saad, O. Y. (2013). The location of economic potentials of a frontier community in Nigeria: an exploit on Ilorin in the $20^{\text {th }}$ century. International journal of Humanities and Social Science invention, 5 , pp. $35-42$.

Nwachukwu, O. (2020). Fire guts Accountant general's office in Abuja. [online] Business Day. Available at: https://businessday.ng/lead-story/article/fire-guts-accountant-generals-office-in-abuja/ [Accessed $5^{\text {th }}$ March 2021].

Shikoli, S. S. (2015). Assessment of use of GIS technology in fire control, case study: Nairobi Country. MSc. Project report submitted to University of Nairobi.

Xiao-tao, W. and Li-ping, W. (2011). Evaluation of fire emergency rescue capability in urban community. Procedia Engineering, 11, pp. 536 - 540.

Waheed, M. A. A. (2014). Approach to fire-related disaster management in high-density urban-area. Procedia Engineering, 77, pp. $61-69$.

Zhang, X., Hu, X. and Li, H. (2019). The evaluation of Emergency rescue capability for general aviation enterprises under specific rescue demand after earthquake. $5^{\text {th }}$ International conference on Transportation information and safety, Liverpool, UK, pp. 56-61.

Zielstra, D. and Zipf, A. (2010). A comparative study of proprietary Geodata and volunteered Geographic information for Germany. $13^{\text {th }}$ AGILE International conference on Geographic Information Science, Guimaraes, Portugal, pp. 1 - 15.

Cite this article as:

Ahmadu H. A., Idrees M. O., Omar D. M., Yusuf A., Ipadeola O. A., Alade A. K. and Abdulyekeen A. O., 2021. Evaluation of Fire Disaster Emergency Response Capacity using Open-source Data and Response Time Analysis in Ilorin Metropolis. Nigerian Journal of Environmental Sciences and Technology, 5(2), pp. 340-346. https://doi.org/10.36263/nijest.2021.02.0281 